\title{
Neotypification of Bauhinia malabarica Roxb. (Fabaceae)
}

\author{
Subir Bandyopadhyay \& Mithilesh Kumar Pathak
}

\section{Abstract}

BANDYOPADHYAY, S. \& M. K. PATHAK (2013). Neotypification of Bauhinia malabarica Roxb. (Fabaceae). Candollea 68: 193-195. In English, English and French abstracts.

A neotype is designated for Bauhinia malabarica Roxb. ( Piliostigma malabaricum (Roxb.) Benth.) (Fabaceae).

\section{Key-words}

FABACEAE - CAESALPINIOIDEAE - Piliostigma - Neotypification

\section{Résumé}

BANDYOPADHYAY, S. \& M. K. PATHAK (2013). Néotypification de Bauhinia malabarica Roxb. (Fabaceae). Candollea 68: 193-195. En anglais, résumés anglais et français.

Un néotype est désigné pour Bauhinia malabarica Roxb. (三Piliostigma malabaricum (Roxb.) Benth.) (Fabaceae).

Address of the authors: Central National Herbarium, Botanical Survey of India, P.O. Botanic Garden, Howrah - 711103, West Bengal, India. 
RoXBURGH (1832: 321) in the protologue of Bauhinia malabarica Roxb. (Fabaceae: Caesalpinioideae) stated "[a] pretty large tree, a native of Malabar, in the Botanic garden at Calcutta, young trees four or five years old from the seed, are about twenty feet high, their stems about as thick as a man's thigh; coma very ramous, with its numerous, smooth, slender, flexuose branchlets, drooping. It begins to blossom in October and November." We referred to STAFLEU \& COWAN (1983) who have stated Roxburgh's main collection to be at K. Substantial duplicate sets are also at BM, BR, E, G, and LIV and small sets at A, B-W, C, DBN, E, FI, NY, OXF, P, PH, and UPS. Consultation of the publication of FORMAN (1997) reveals that there is no Roxburgh collection of B. malabarica at $\mathrm{K}$. We communicated with the curators of all the other aforesaid herbaria and found that there are Roxburgh collections of B. malabarica only in E, BM and P.

The herbarium sheet of B. malabarica at E [E00499899] has a small label with the name Roxburgh written on it. This specimen comprises two mature and a few immature leaves, besides, two separate leaves and two separate pods mounted on the sheet. They are, however, not on B. malabarica, and are likely to be from a specimen of $B$. purpurea $\mathrm{L}$. There is an inscription on the sheet written in pencil: "B. malabarica" accompanied by a question mark, this annotation probably by David Prain. The herbarium sheet at BM [BM001001035] has a label on which is written: "India Orientalis - Dr. Roxburgh (1813)" with the name "Bauhinia malabarica" written on a separate piece of paper. There are three specimens mounted on this sheet and all of them are of B. malabarica. The top specimen is sterile (leaves only). The middle and bottom specimens have male inflorescences and leaves. Although RoxBURGH (1832: 321) in his protologue of B. malabarica described only male flowers, there is no evidence that he used these specimens to describe B. malabarica nor that any of them represent a duplicate of the specimen(s) actually used by him. The handwriting on the sheet does not match that of Roxburgh (see FoRMAN, 1997). The herbarium sheets at P [P02744676 and P02744679] carry labels on which is written: "Roxburgh, India" together with "Bauhinia malabarica" on separate slips of paper. The handwriting style of "Bauhinia malabarica" on specimen P02744676 is very similar to that on BM [BM00100 1035] and does not match that of Roxburgh.

There is no Roxburgh's "Flora Indica" drawing of B. malabarica at K (SEALY, 1956) or CAL (SANJAPPA \& al., 1994).

Due to the lack of any conclusive evidence that any of the above mentioned specimens are part of the original type material we here propose as a neotype of B. malabarica Roxb. a specimen which was originally part of Roxburgh's herbarium.
Bauhinia malabarica Roxb., Fl. Ind. ed. 1832: 321. 1832.

= Bauhinia malabarica Roxb., Hort. Bengal.: 31. 1814 [nom. nud.].

$\equiv$ Piliostigma malabaricum (Roxb.) Benth. in Miq., Pl. Jungh.: 261. 1852.

Neotypus (designed here): INDIA: India Orientalis, 1813, Roxburgh s.n. (BM [BM001001035], arrow) (Fig. 1).

\section{Acknowledgements}

We thank the Director, Botanical Survey of India and Additional Director, Central National Herbarium, BSI for facilities, the curators of K, BM, BR, E, G, LIV, A, B-W, C, DBN, E, FI, NY, OXF, P, PH, and UPS for their help and Jonathan Gregson, at the Natural History Museum, London for kindly informing us that both specimens mounted on the BM sheet have male inflorescences.

\section{References}

FORMAN, L. L. (1997). Notes concerning the typification of names of William Roxburgh's species of phanerogams. Kew Bull. 52: 513-534.

Roxburgh, W. (1832). Bauhinia. Fl. Ind. ed. Carey 2: 318-332. Calcutta, London.

SANJAPPA, M., K. THOthathri \& A. R. DAS (1994). Roxburgh's Flora Indica drawings at Calcutta. Bull. Bot. Surv. India 33.

SEALY, J. R. (1956). The Roxburgh Flora Indica Drawings at Kew. Kew Bull. 11: 297-348.

Stafleu, F. A. \& R. S. Cowan (1983). Taxonomic Literature. Vol.4. Bohn, Scheltama \& Holkenia. 


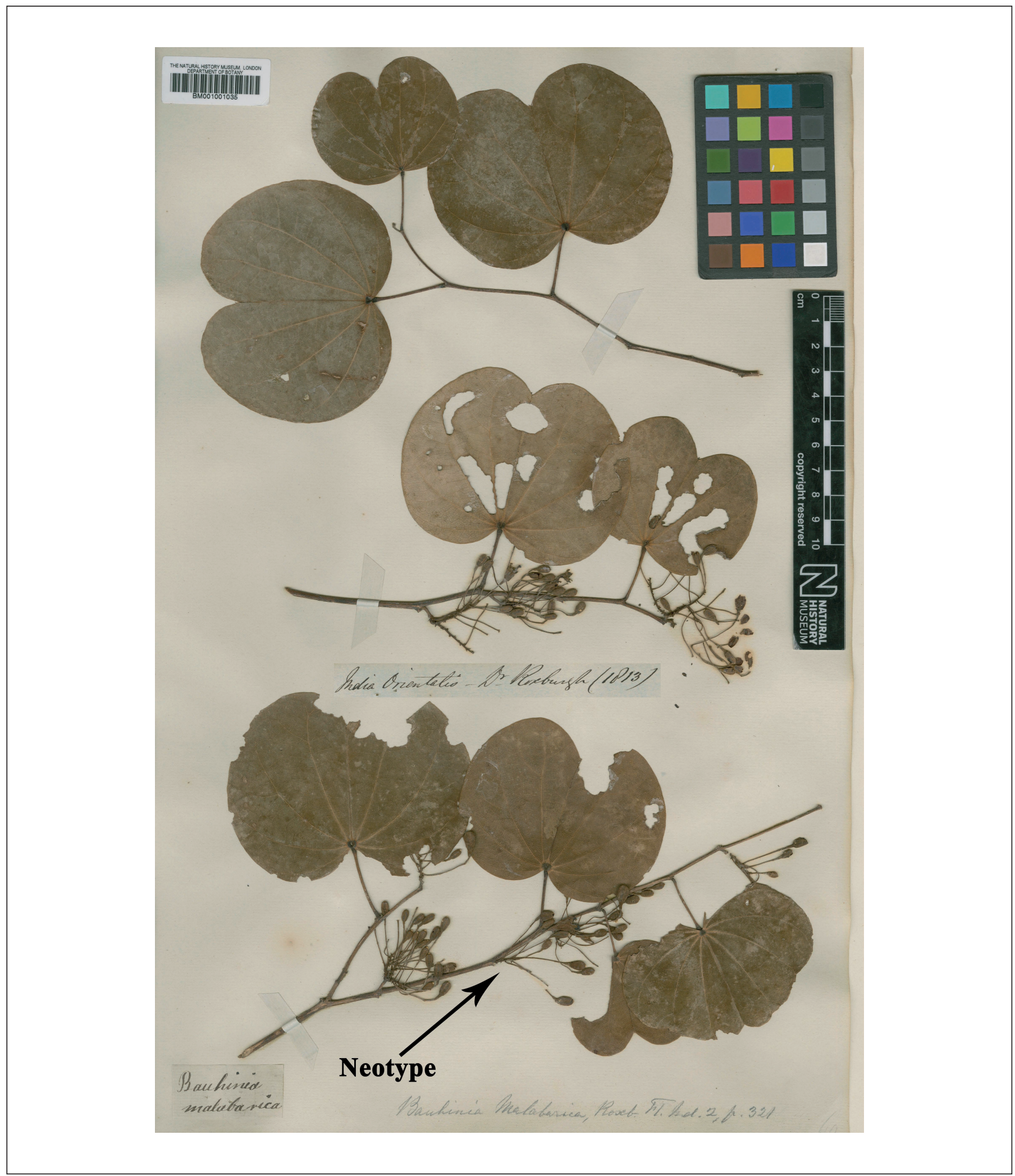

Fig. 1. - Neotype of Bauhinia malabarica Roxb. (designated by an arrow).

[Roxburgh s.n., BM] [@ Natural History Museum, London. Reproduced with permission] 